Article

\title{
Solar Decathlon Latin America and Caribbean: Comfort and the Balance between Passive and Active Design
}

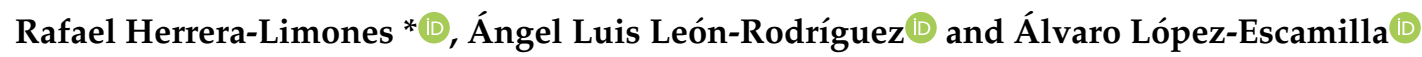 \\ Instituto Universitario de Arquitectura y Ciencias de la Construcción, Escuela Técnica Superior de Arquitectura, \\ Universidad de Sevilla, Av. Reina Mercedes 2, 41012 Seville, Spain \\ * Correspondence: herrera@us.es; Tel.: +34-954-55-65-20
}

Received: 12 April 2019; Accepted: 21 June 2019; Published: 26 June 2019

check for updates

\begin{abstract}
This article contains an overall analysis of the results obtained by the four highest scoring teams in the Solar Decathlon Latin America and Caribbean 2015 collegiate sustainable habitat competition. Considering that the prototypes developed were based on energy self-sufficiency when operational, it was considered necessary to propose this analysis based on the degree of suitability of each of these models based on their different performances from the perspective of comfort conditions. It was observed that the design of the prototypes did not manage to properly adjust the relationship between passive and active conditioning elements based on the location's conditions. Accordingly, this article concludes that a balance of the two aforementioned conditioning modes recorded better results based on the measurements taken.
\end{abstract}

Keywords: architecture; solar; prototype; competition; environmental; conditioning; active; passive; university

\section{Introduction}

The building sector consumes too many natural resources and is responsible for enormous $\mathrm{CO}_{2}$ emissions into the atmosphere $[1,2]$. Therefore, architectural styles must be found that minimize their environmental impact $[3,4]$.

This article is based on a line of research aimed primarily at searching for construction models that minimize environmental impact based on an alignment with the Horizon 2020 (European Union Framework Program, the strategic objectives of which are aimed at scientific excellency and developing technologies), and the UNESCO and Sustainable Development Goals for 2030 (in particular, goal 11: Sustainable cities and communities).

It is based on the premise that in the search for sustainable architectural models, competitions dedicated to generating ideas that are responsive to passive conditioning strategies, as well as maximizing efficiency and self-sufficiency, can and should be a primary research field when it comes to refining future building prototypes.

The Solar Decathlon Competition is the most prestigious sustainable habitat competition on the planet. In collaboration with institutions and companies, universities from all over the world participate with the aim of designing, building, and putting into operation an exhibition pavilion in the form of a housing prototype, with the highest level of self-sufficiency and use of renewable energies.

However, the final construction (which has the dual purpose of acting as both a pavilion that can be visited as well as a prototype that can be monitored) is not the sole purpose of the competition, but rather in the educational and research process, the prototypes undergo the following 10 contests (hence the name decathlon): Architecture, engineering, and construction; energy efficiency; electrical 
balance; comfort conditions; sustainability; housing functionality; communications and marketing; urban design; and innovation.

In this manner, the decathletes (recently graduated or final-year university students), mentored by teachers and researchers from different knowledge areas, comprise an inter-disciplinary team that takes on the competitive process as a tool for learning through problem solving, ultimately constituting an exceptional framework for exchanging information and an effective forum for transmitting knowledge gained in academia.

The Solar Decathlon Latin America and Caribbean (hereinafter SDLAC) 2015, held in Cali (Colombia), was a pioneer in displaying a certain concern for regional relevance and social housing [5], unlike previous editions of the competition. This was the first edition of the contest held in Latin America: Due to the cultural and climatic context of the competition, it seems particularly suitable for an analysis of the confrontation between the active and the passive, as far as conditioning is concerned.

The main objective of this article is to show which conditioning strategies are the most suitable for the general context of the Latin American Solar Decathlon Competition, in particular for Colombia (in the city of Santiago de Cali), since this is the specific location of the first competition of its type in the American subcontinent, SDLAC 2015.

Accordingly, it follows that this article is appropriate for two reasons: Firstly, to consider (from a temporal perspective) the experience acquired in this competition; and secondly, to confirm that current research into sustainable habitats continues to take place. The latter is confirmed by the announcement of the upcoming SDLAC in December 2019 (also to be held in Colombia), which will be attended by the University of Seville, among others.

Therefore, a second objective of this study is to show and analyze the results obtained in the 2015 edition of the competition so that this university experience can be used in the next edition, which will take place in the same city (Santiago de Cali) in December 2019, in which the University of Seville team will compete with a new proposal.

Finally, to clarify the purpose of the research in this article, the possibility of transferring the most successful prototypes from the previous SDLAC15 competition, in terms of the proper balance between active and passive conditioning strategies, will be considered, this being understood as a clear indication of environmental innovation, which could even lead to real everyday models that could contribute to reducing environmental impact on a broad scale.

In order to build on the above, the specific original methodology described below was used.

\section{Methodology}

Considering that this is a complex problem that must be analyzed from a singular environmental context (tropical climate and social housing), a two-part methodology is proposed: The first part was based on analyzing the latest advances on the subject and the second focuses on the results obtained in the Solar Decathlon Latin America and Caribbean 2015 competition (SDLAC). These two stages of analysis are represented in Figure 1.

In turn, the first stage of analysis was carried out in three stages:

- Firstly, the latest advances in relation to the aim of the competition were analyzed, considering the current strategies/technologies for improving environmental and energy conditions in social housing. In order to do so, a literature review was conducted (mainly scientific articles). With the results from this, a database was developed that can be referenced with the aims and results of the SDLAC competition.

- Secondly, the current legislation was analyzed with regard to design and environmental conditioning, both in the country where the competition takes place (Colombia) as well as in other reference countries (Spain). By doing so, the aim was to link the legislative conditions and environmental conditioning strategies (both passive and active) that are applicable to the construction of social housing in a tropical climate. 
- Lastly, the rules and guidelines for the different editions of the Solar Decathlon competition were analyzed, displaying their scoring criteria. This information was connected to the literature and legislation of the previous sections in order to verify how far this competition can help to transfer beneficial results into society.

The second stage contains a synthetic analysis of the results obtained by the top four teams in the SDLAC 2015 competition: 1. Casa Uruguaya/Universidad ORT (Uruguay); 2. Casa ALERO/Pontificia U. Javeriana and U. Icesi de Cali (Colombia); 3. AURA Prototype/Universidad de Sevilla (Spain) and U. Santiago de Cali (Colombia); and 4. unSOLAR/U. Nacional de Medellín (Colombia). The four prototypes were compared to the context defined in the first stage and the capacity for transferring knowledge and solutions into society was analyzed, in the context of "social housing in a tropical climate."

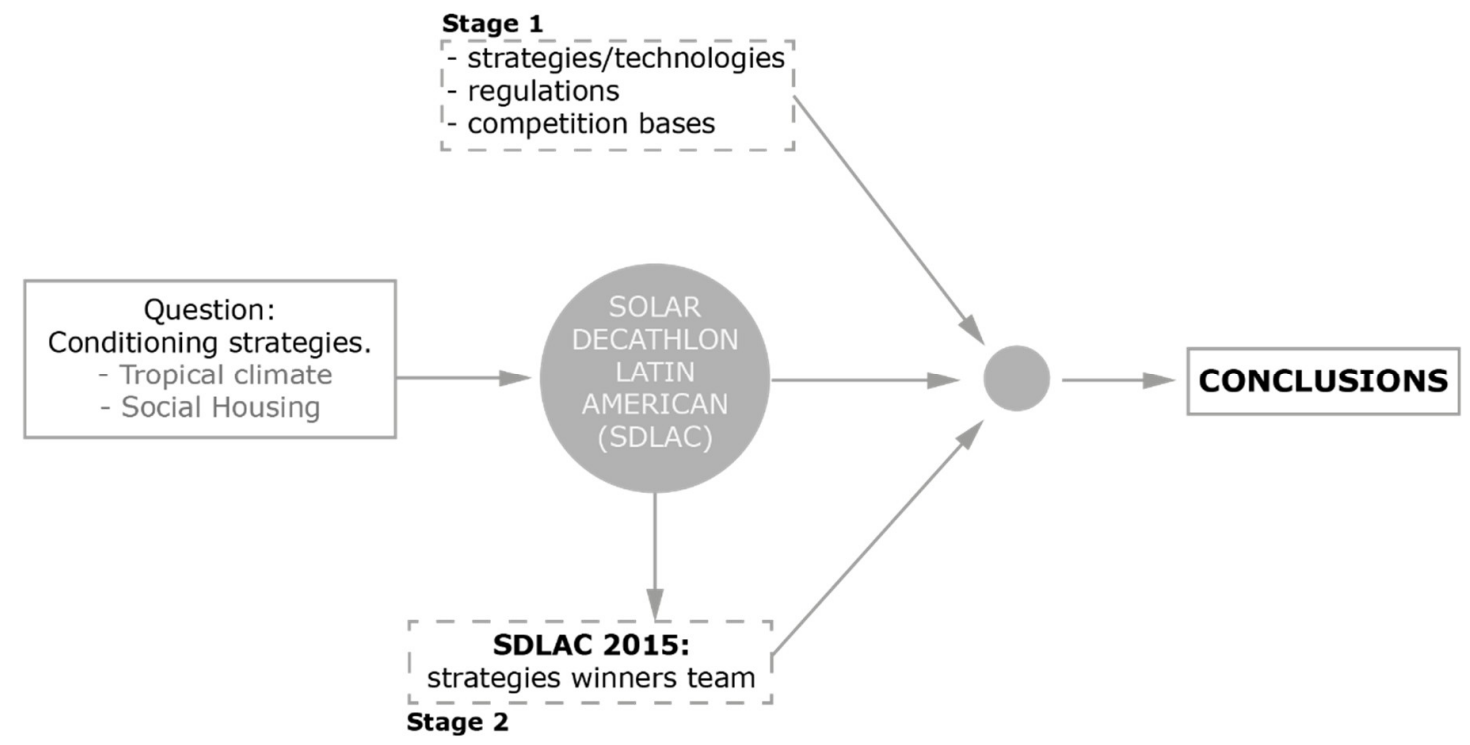

Figure 1. Diagram of the process.

\section{Literature Review}

\subsection{History and Timeline of the Solar Decathlon}

The international Solar Decathlon competition, the most prestigious collegiate competition related to sustainable social habitat throughout the world, took place for the first time in Washington D.C. in 2002, organized by the US Department of Energy. Since then, it has been held every two years in various North American cities.

However, from 2010, the competition has also taken place on other continents, with Spain being the first country to host this event outside of the United States. Subsequently, there were two more editions of the European version of the competition, with the fourth edition being in process (in Hungary) and a fifth edition planned for 2021.

China, Africa, the Middle East, and Latin America are the other areas where this collegiate competition has been held (Table 1), although their histories are shorter as fewer editions have taken place in each of these settings.

Although each of the six Solar Decathlon competitions has different rules, what never changes is the essence of the competition. These are 10 points-based contests on which each team is assessed. The winning team is the one that best combines excellency in design and the production of intelligent energy with innovation, market potential, efficiency, sustainability, and the water cycle, etc.

Since it began in 2002, the competition has held (or is planning to hold or is even currently holding) the following versions in the following locations: 
Table 1. Timeline of editions of the Solar Decathlon competition.

\begin{tabular}{|c|c|c|}
\hline SOLAR DECATHLON & COUNTRY & YEAR \\
\hline \multirow{8}{*}{ US } & Washington D.C. & 2002 \\
\hline & Washington D.C. & 2005 \\
\hline & Washington D.C. & 2007 \\
\hline & Washington D.C. & 2009 \\
\hline & Washington D.C. & 2011 \\
\hline & Irvine, California & 2013 \\
\hline & Irvine, California & 2015 \\
\hline & Denver, Colorado & 2017 \\
\hline Africa & Ben Guerir, Morocco & 2019 \\
\hline \multirow{2}{*}{ China } & Datong & 2013 \\
\hline & Dezhou & 2018 \\
\hline \multirow{5}{*}{ Europe } & Madrid, Spain & 2010 \\
\hline & Madrid, Spain & 2012 \\
\hline & Paris-Versailles, France & 2014 \\
\hline & Szentendre-Budapest, Hungary & 2019 \\
\hline & Wuppertal, Germany & 2021 \\
\hline \multirow{2}{*}{ Latin America and Caribbean } & Santiago de Cali, Colombia & 2015 \\
\hline & Santiago de Cali, Colombia & 2019 \\
\hline \multirow{2}{*}{ Middle East } & Dubai, United Arab Emirates & 2018 \\
\hline & Dubai, United Arab Emirates & 2020 \\
\hline
\end{tabular}

\subsection{Conditioning Strategies, Legislation, and Competition Rules}

We started this literature review with a selective and synthetic study of the current zero-energy building strategies, which may be classified into passive energy saving systems, production technologies, and storage of renewable energies, on the one hand, and efficient energy service systems, on the other [6-8].

The last column of Table 2 indicates the bibliographic references that justify the inclusion of the various technologies/strategies and procedures. The reference selection was based on databases with recognized scientific prestige and validity, thus obtaining an updated review of the technologies and strategies studied in this article.

Regarding the above table, it is worth clarifying that the competition's host country, Colombia, presents a wide variety of climates; however, given the specific location of the event (Santiago de Cali), it is the warm/tropical climate strategies that are the most interesting in this case. 
Table 2. Technologies and strategies: cross-referenced with bibliographic references.

\begin{tabular}{|c|c|c|}
\hline \multicolumn{3}{|c|}{ PASSIVE ENERGY SAVING SYSTEMS } \\
\hline \multirow{6}{*}{ ENCLOSURE } & Form Factor/Modulation:/Flexibility/Prefabrication & {$[9,10]$} \\
\hline & Solar shading & {$[9,11,12]$} \\
\hline & Ventilated façade & {$[13,14]$} \\
\hline & Thermal insulation & [15] \\
\hline & Low-emission openings (Low-E) & {$[9,16]$} \\
\hline & Active user & [17] \\
\hline \multirow{4}{*}{ PASSIVE HEATING } & Solar roof & {$[18,19]$} \\
\hline & Trombe wall & [18] \\
\hline & Curtain wall & {$[20]$} \\
\hline & Greenhouse & [9] \\
\hline \multirow{5}{*}{ PASSIVE COOLING } & Natural ventilation & {$[4,9,11,21,22]$} \\
\hline & Earth-air heat exchanger (EAHE) & [23] \\
\hline & Adiabatic cooling/Evaporative cooling & {$[9,18]$} \\
\hline & Green roof & [24] \\
\hline & Dehumidification & [25] \\
\hline THERMAL ENERGY STORAGE & $\begin{array}{c}\text { Phase change materials (PCM) } \\
\text { Thermal inertia }\end{array}$ & [26-28] \\
\hline \multicolumn{3}{|c|}{ EFFICIENT ENERGY SERVICE SYSTEMS } \\
\hline \multirow[t]{2}{*}{ SOLAR ENERGY } & $\begin{array}{c}\text { Photovoltaic panels } \\
\text { Architectural integration } \\
\text { Photovoltaic panels for façades }\end{array}$ & {$[4,9,11,12,29-32]$} \\
\hline & Hybrid photovoltaic/thermal systems & {$[9,33]$} \\
\hline WIND POWER & Wind turbines & [34] \\
\hline GEOTHERMAL POWER & Geothermal heat pump & [35] \\
\hline \multirow{2}{*}{ BIOENERGY } & Biomass boiler & {$[36,37]$} \\
\hline & Biofuels & [38] \\
\hline ENERGY STORAGE & Batteries & {$[39,40]$} \\
\hline \multirow{5}{*}{$\begin{array}{c}\text { HVAC } \\
\text { (Heating, Ventilating and } \\
\text { Conditioning systems) }\end{array}$} & Evaporative cooling & [41] \\
\hline & Active thermal storage & [42] \\
\hline & Heat recovery & {$[37,43,44]$} \\
\hline & Radiative heating/cooling & [45] \\
\hline & Variable air volume (VAV)/variable coolant volume & {$[46,47]$} \\
\hline \multirow{3}{*}{ DWH } & $\begin{array}{l}\text { Solar water heating }(\mathrm{SWH}) \\
\text { - Flat plate collectors } \\
\text { - Vacuum tube collectors }\end{array}$ & {$[9,14,32,35,48]$} \\
\hline & Solar heat pump system & {$[37,49]$} \\
\hline & Combined cooling/heating and power (CCHP) & {$[37,50]$} \\
\hline \multirow{2}{*}{ LIGHTING } & Light-emitting diodes (LED) & {$[51]$} \\
\hline & Use of daylight & [52] \\
\hline \multirow{2}{*}{ HOUSEHOLD EQUIPMENT } & Efficient appliances & {$[9,32,53]$} \\
\hline & Domotics/Monitoring/Automation & {$[17,30,54]$} \\
\hline \multirow{2}{*}{ WATER CYCLE } & Greywater recycling & {$[11,30]$} \\
\hline & Use of rainwater & [11] \\
\hline
\end{tabular}


After analyzing the regulations of the countries being studied (Colombia and Spain), it is clear that the implementation of a certain technology in the architectural process must pass through a legal and regulatory filter. It is for this reason that an updated review of the energy efficiency legislation and renewable energies regulations in both Colombia [55] and Spain [56] was carried out, these countries being the location of SDLAC15 and the field of work of the authors of the article, respectively, which could be assimilated to Latin America vs. Europe.

Table 3 shows that although it is true that in Colombia (and in other Latin American countries with similar levels of development) there is a high level of interest in the promotion of renewable energies, in order for this interest to take shape rather than remaining a desire, it is essential that regulations are developed that enable zero-energy building technologies to be implemented.

Table 3. Colombian legislation on energy efficiency and renewable energies.

\begin{tabular}{|c|c|c|}
\hline $\begin{array}{l}\text { LEGISLATIVE } \\
\text { FRAMEWORK }\end{array}$ & SPAIN (Europe) & COLOMBIA (Latin America) \\
\hline $\begin{array}{l}\text { General legislation } \\
\text {-energy efficiency }\end{array}$ & $\begin{array}{l}\text { Current Energy Efficiency Directive 2012/27/EU, with } \\
\text { regard to directives 2006/32/EC and 93/76/EEC }\end{array}$ & $\begin{array}{l}\text { Law } 697 \text { of } 2001 \text { on the rational and efficient use } \\
\text { of energy }\end{array}$ \\
\hline Efficiency Agency & $\begin{array}{l}\text { Institute for the Diversification and Saving of Energy } \\
\text { (IDAE) }\end{array}$ & Does not exist \\
\hline Action plans & Energy Saving and Efficiency Action Plan 2011-2020 & $\begin{array}{c}\text { Program for the Rational and Efficient Use of } \\
\text { Energy and other Non-Conventional Energy } \\
\text { Sources, PROURE }\end{array}$ \\
\hline \multicolumn{3}{|c|}{ BUILDINGS } \\
\hline $\begin{array}{l}\text { Energy performance } \\
\text { requirements in } \\
\text { buildings }\end{array}$ & $\begin{array}{l}\text { Technical Building Code (CTE)(RD } 31472006 \text { and } \\
\text { 1371/2007) }\end{array}$ & $\begin{array}{l}\text { Does not exist. Only one proposal has been } \\
\text { submitted for Regulation of Technical Energy } \\
\text { Efficiency for Social Housing (RETEVIS). }\end{array}$ \\
\hline Energy certificate & $\begin{array}{l}\text { RD 235/2013, which approves the basic procedure for } \\
\text { certifying the energy efficiency of buildings }\end{array}$ & Does not exist \\
\hline Savings objective & $\begin{array}{l}\text { Technical Building Code-Basic Document HE on } \\
\text { Energy Savings }\end{array}$ & Does not exist \\
\hline $\begin{array}{l}\text { Requirements for } \\
\text { thermal installations }\end{array}$ & $\begin{array}{l}\text { Regulation of Thermal Installations in RITE Buildings } \\
\text { (RD 1027/2007 and 1826/2009) }\end{array}$ & Does not exist \\
\hline \multicolumn{3}{|c|}{ LIGHTING } \\
\hline $\begin{array}{l}\text { Energy performance } \\
\text { requirement }\end{array}$ & $\begin{array}{c}\text { Technical Building Code-Basic Document HE.3 (Energy } \\
\text { efficiency of lighting installations) and Regulation on } \\
\text { Energy Efficiency in Outdoor Lighting Installations (RD } \\
1890 / 2008)\end{array}$ & $\begin{array}{l}\text { Technical Regulation on Lighting and Street } \\
\text { Lighting RETILAP (Resolution } 181331 \text { of } 2009 \\
\text { and modified by resolution } 180540 \text { of } 2010 \text { by } \\
\text { which the requirements of light efficiency and } \\
\text { other provisions are established) }\end{array}$ \\
\hline Removal of lamps & $\begin{array}{l}\text { Commission Regulation (EU) 2015/1428, amending } \\
\text { Commission Regulation (EC) 244/2009 as regards } \\
\text { ecodesign requirements for non-directional household } \\
\text { lamps and Commission Regulation (EC) 245/2009 }\end{array}$ & $\begin{array}{l}\text { Decree } 2331 \text { of 2007, which establishes a measure } \\
\text { aimed at the rational and efficient use of } \\
\text { electricity. Compiled Decree } 1073 \text { of } 2015\end{array}$ \\
\hline Labelling Regulation & $\begin{array}{c}\text { Regulation 874/2012/EU, which complements Directive } \\
\text { 2010/30/EU of the European Parliament and of the } \\
\text { Council regarding the energy labelling of electric lamps } \\
\text { and lights }\end{array}$ & $\begin{array}{l}\text { Technical Labelling Regulation (RETIQ). Decree } \\
1471 \text { of } 2014\end{array}$ \\
\hline \multicolumn{3}{|c|}{ APPLIANCES AND EQUIPMENT } \\
\hline $\begin{array}{l}\text { Energy performance } \\
\text { requirement }\end{array}$ & $\begin{array}{l}\text { RD 187/2011, regarding the establishment of ecodesign } \\
\text { requirements applicable to energy-related products }\end{array}$ & Does not exist \\
\hline Energy labelling & $\begin{array}{c}\text { RD 1390/2011, which regulates the indication of energy } \\
\text { consumption and other resources for energy-related } \\
\text { products, through labelling and standardized } \\
\text { information }\end{array}$ & $\begin{array}{l}\text { Technical Labelling Regulation (RETIQ). Decree } \\
1471 \text { of } 2014\end{array}$ \\
\hline \multicolumn{3}{|c|}{ ENERGY SUPPLY } \\
\hline Cogeneration & $\begin{array}{l}\text { RD } 413 / 2014 \text {, which regulates the activity of producing } \\
\text { electricity from renewable energy sources, cogeneration } \\
\text { and waste. Supreme Court judgement BOE } 245 \text { of } 10 / 10 / 2016\end{array}$ & $\begin{array}{c}\text { Law } 1715 \text { of 2014, which regulates the integration } \\
\text { of non-conventional renewable energies into the } \\
\text { national energy system }\end{array}$ \\
\hline \multicolumn{3}{|c|}{ ECONOMIC INSTRUMENTS } \\
\hline $\begin{array}{l}\text { Industrial and } \\
\text { commercial sector }\end{array}$ & $\begin{array}{l}\text { Aid programs managed by the IDAE under the National } \\
\text { Energy Efficiency Fund (FNEE) }\end{array}$ & $\begin{array}{l}\text { Fiscal measures limited to the indicative plans of } \\
\text { PROURE }\end{array}$ \\
\hline $\begin{array}{l}\text { Residential sector } \\
\text { and individuals }\end{array}$ & $\begin{array}{l}\text { Program for Energy Refurbishment of Buildings } \\
\text { (PAREER-CRECE) }\end{array}$ & Does not exist \\
\hline
\end{tabular}


Current Colombian laws do not establish binding objectives and the available economic incentives are indirect [55]. An example of this is the construction sector, for both new buildings and refurbishments (Table 3, BUILDINGS section), which entirely lacks any legislative framework that imposes energy efficiency measures and strategies.

Moving on to the analysis of the competition rules [2], we must point out that these are focused on a series of objectives that are part of the spirit of the competition (Table 4). Thus, based on the process of building sustainable housing cell prototypes, we seek to educate in terms of environmental awareness and serve as a training activity for the members of the participating teams.

Table 4. Analysis of the 10 contests of the competition: summary table generated from the SDLAC15 Competition Rules, but with our own re-drafting.

\begin{tabular}{|c|c|c|c|c|}
\hline CONTEST & \multicolumn{2}{|c|}{ DESCRIPTION } & SCORING & JUDGING \\
\hline Architecture & \multicolumn{2}{|c|}{$\begin{array}{l}\text { Evaluates spatial efficiency, the adequacy of the materials in } \\
\text { relation to bioclimatic strategies for the future of social } \\
\text { housing in the context of Latin America and the Caribbean. }\end{array}$} & 100 & Judges \\
\hline $\begin{array}{l}\text { Engineering and } \\
\text { construction }\end{array}$ & \multicolumn{2}{|c|}{$\begin{array}{l}\text { Evaluates feasibility and adequate integration of the structural, } \\
\text { electrical, plumbing, and solar design and that of the enclosure } \\
\text { for low-cost social housing. }\end{array}$} & 100 & Judges \\
\hline \multirow{2}{*}{ Energy efficiency } & \multirow{2}{*}{$\begin{array}{l}\text { Evaluates suitable design of the } \\
\text { dwelling's systems to achieve a } \\
\text { reduction in energy consumption. }\end{array}$} & Energy efficiency & 60 & \multirow{2}{*}{ Monitoring } \\
\hline & & $\begin{array}{l}\text { Limiting energy } \\
\text { consumption }\end{array}$ & 40 & \\
\hline \multirow{2}{*}{ Electrical balance } & \multirow{2}{*}{$\begin{array}{l}\text { Measures the level of electrical } \\
\text { self-sufficiency of the dwelling } \\
\text { through balancing electricity } \\
\text { generation and consumption. }\end{array}$} & $\begin{array}{c}\text { Electrical } \\
\text { balance }\end{array}$ & 60 & \multirow{2}{*}{ Monitoring } \\
\hline & & $\begin{array}{l}\text { Consumption } \\
\text { peaks }\end{array}$ & 40 & \\
\hline \multirow{4}{*}{ Comfort conditions } & \multirow{4}{*}{$\begin{array}{l}\text { Measures interior conditions, such } \\
\text { as temperature, humidity, } \\
\text { acoustics, lighting, and air quality, } \\
\text { to assess the sensation of interior } \\
\text { comfort in each housing solution. }\end{array}$} & Thermal comfort & 50 & \multirow{4}{*}{ Monitoring } \\
\hline & & Relative humidity & 20 & \\
\hline & & $\begin{array}{l}\text { Natural and artificial } \\
\text { lighting }\end{array}$ & 20 & \\
\hline & & Acoustic performance & 20 & \\
\hline Sustainability & \multicolumn{2}{|c|}{$\begin{array}{l}\text { Focused on reducing environmental impact in the long term. } \\
\text { Evaluates strategies to properly manage the topics of } \\
\text { architecture, engineering and construction, energy efficiency, } \\
\text { urban design, and economic viability. }\end{array}$} & 100 & Judges \\
\hline \multirow{10}{*}{$\begin{array}{l}\text { Housing } \\
\text { functionality }\end{array}$} & \multirow{10}{*}{$\begin{array}{l}\text { Measures the efficiency and } \\
\text { functionality of a set of } \\
\text { applications to ensure normal } \\
\text { functioning of the dwelling. }\end{array}$} & Cooling & 8 & \multirow{10}{*}{ Test } \\
\hline & & Freezer & 8 & \\
\hline & & Washing machine & 12 & \\
\hline & & Microwave & 5 & \\
\hline & & Blender & 5 & \\
\hline & & Kitchen & 10 & \\
\hline & & Appliances & 7 & \\
\hline & & Social activity & 15 & \\
\hline & & $\begin{array}{l}\text { Minimizing water } \\
\text { consumption }\end{array}$ & 10 & \\
\hline & & Hot running water & 20 & \\
\hline $\begin{array}{l}\text { Communications } \\
\text { and marketing }\end{array}$ & $\begin{array}{r}\text { Evaluates the effectiveness and ef } \\
\text { communications strategies to gene } \\
\text { projects and the advantages of us } \\
\text { with a solar energ }\end{array}$ & $\begin{array}{l}\text { iency of marketing and } \\
\text { te social awareness of the } \\
\text { g sustainable buildings } \\
\text { supply. }\end{array}$ & 100 & Judges \\
\hline $\begin{array}{l}\text { Urban design and } \\
\text { affordability }\end{array}$ & $\begin{array}{l}\text { Promotes research into urban desig } \\
\text { to the context of Latin America and } \\
\text { effective and innovative proposal }\end{array}$ & $\begin{array}{l}\text { with a density applicable } \\
\text { e Caribbean to achieve an } \\
\text { sed on low-cost housing. }\end{array}$ & 100 & Judges \\
\hline Innovation & $\begin{array}{r}\text { Evaluates the incorporation of cre } \\
\text { conventional levels o }\end{array}$ & $\begin{array}{l}\text { ive solutions to improve } \\
\text { habitability. }\end{array}$ & 100 & Judges \\
\hline
\end{tabular}

However, the specific rules of the Latin American Solar Decathlon are excessively based on the rules of the competition's previous editions (in North America or Europe), meaning they lack greater 
suitability for the context, both in the contests presented and in the conditioning strategies that could be possible as a result.

Alternatively, the fact of the competition organizers disallowing the storage of energy by means of batteries seems odd (in previous editions of the Solar Decathlon, this prohibition did not exist). This is especially true considering the Colombian electrical system is divided between the national interconnected system (SIN) and the ZNI, or geographic areas where the public electricity service is not available [57], and where the implementation of electric energy storage batteries could be an efficient alternative.

\section{Comparative Analysis of the Winning Prototypes}

We will start this comparative analysis by studying the specific results of the SDLAC15 competition, in particular the four teams that finished with the highest scores after 15 days of competition, which are as follows:

\section{- First Prize: Casa Uruguaya/Universidad ORT (Uruguay)}

This prototype consisted of a closed pavilion, very dependent on technology and active conditioning strategies (Figure 2). However, vertical solar shading was used through an outer layer on its perimeter, with the aim of generating a microclimate between the house and the exterior, thus protecting it from direct sunlight. Low impact materials, such as wood or glass wool, were used with the intention of obtaining low greenhouse gas emissions and generating a reduced ecological footprint. In addition, it was equipped with a system that enables rainwater to be reused for watering plants and hydroponic systems.

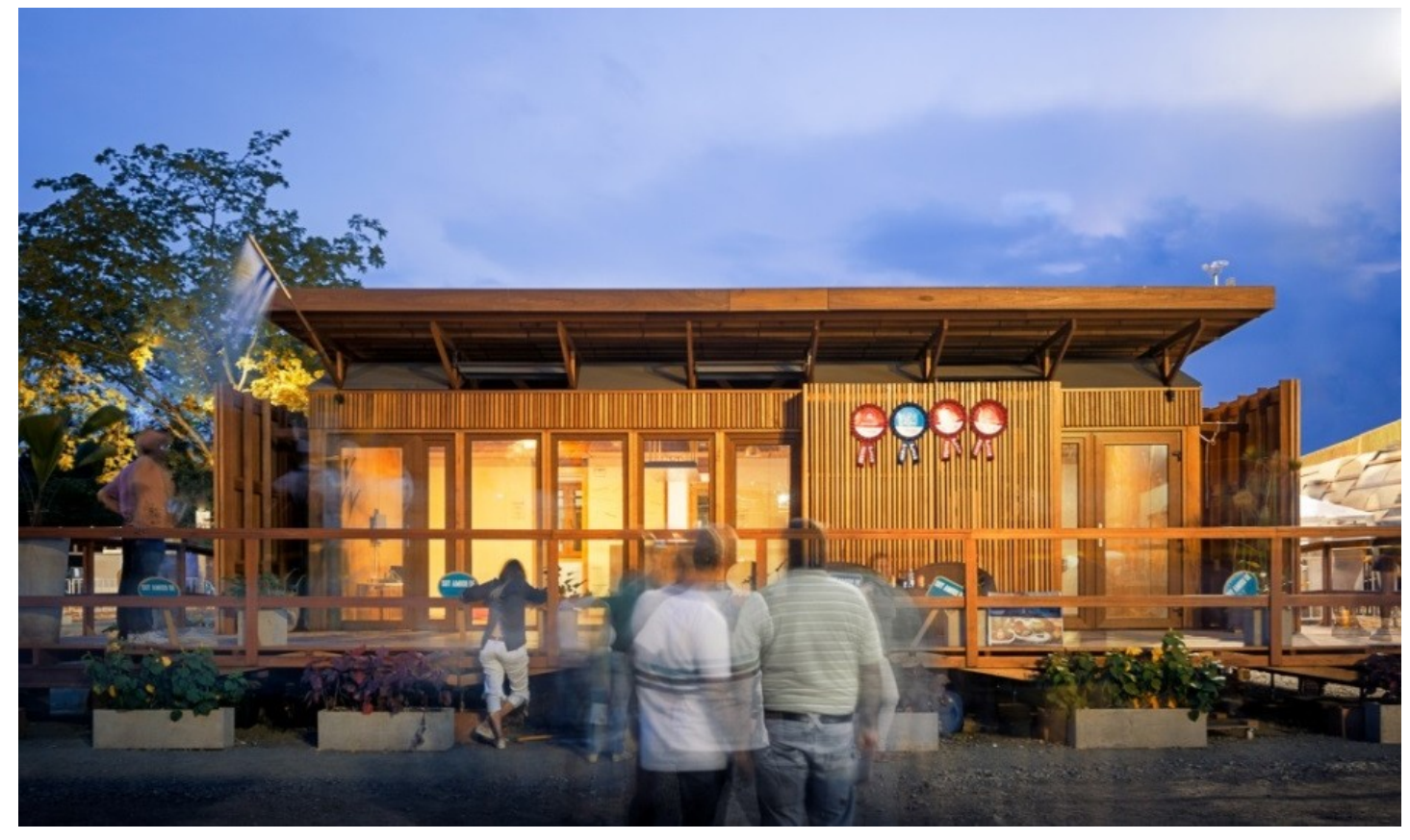

Figure 2. North side of Casa Uruguaya.

Furthermore, it should be noted that the dwelling was equipped with domotic energy control, enabling the occupant to be informed of the energy demand by the use of a mobile device in order to control the humidity and temperature, depending on atmospheric conditions, with the objective of adjusting the energy balance.

- Second Prize: Casa ALERO/Pontificia U. Javeriana and U. Icesi de Cali (Colombia) 
Unlike the previous example, this team presented a completely open prototype with comfort conditions that were based entirely on passive conditioning, which fluctuate depending on the external conditions (Figure 3). As a result, it was highly dependent on these factors during the final phase of the competition (which, on this occasion, were favorable since there were no rainfalls or excessive temperatures during the competition period).

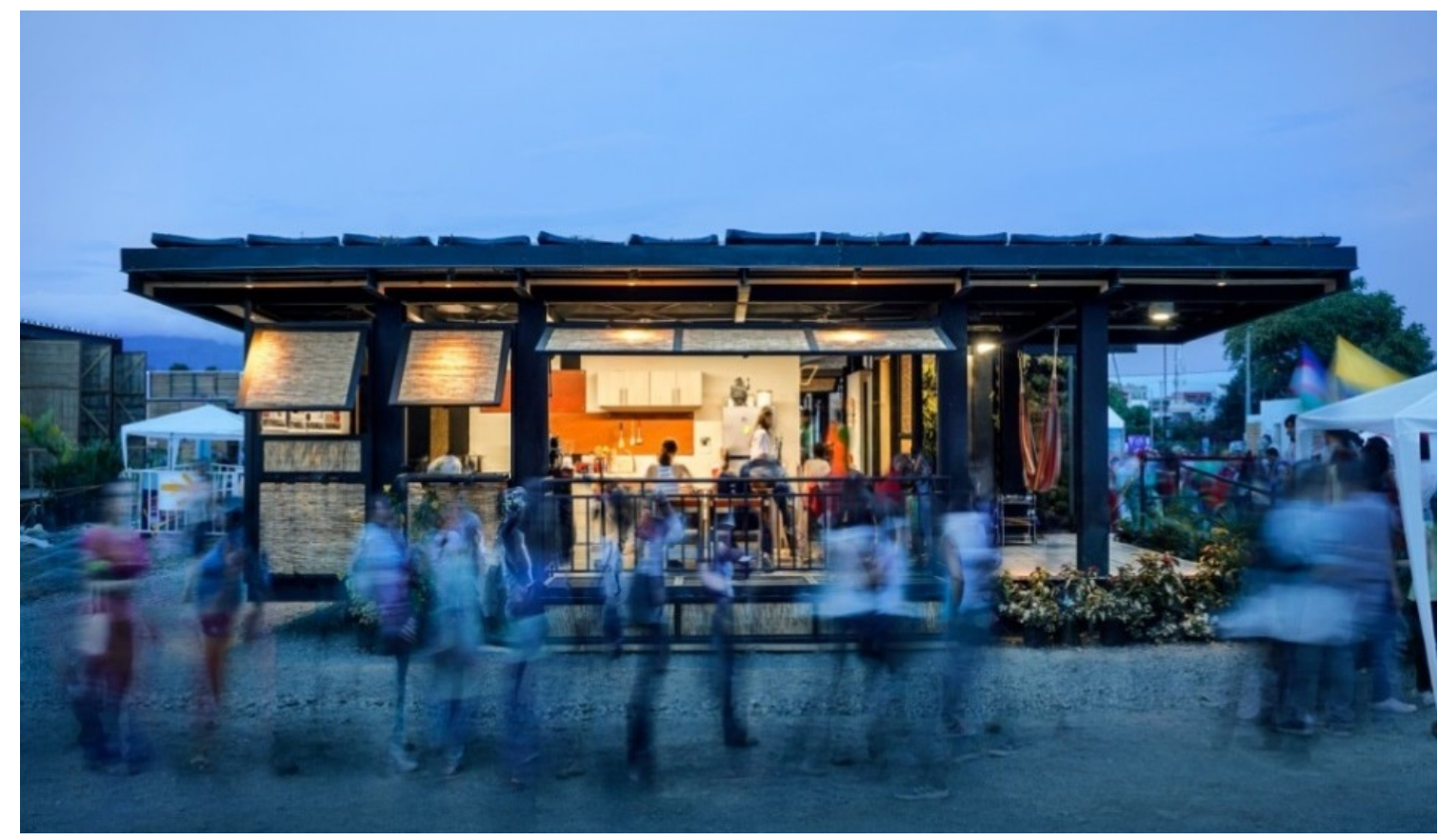

Figure 3. South side of Casa ALERO.

The operation of the model is based, fundamentally, on its roof, which was designed to provide solar shading at the latitude of Santiago de Cali, and was planted with vegetation to offset the effects of direct solar radiation. The proposal was complemented by a series of balconies that were completely permeable and collapsible, converting the entire house into a covered but open space, as an extension of the outdoor space.

- Third Prize: AURA Prototype/U. de Sevilla (Spain) and U. Santiago de Cali (Colombia)

Unlike the two previous prototypes, this prototype sought a balance, combining both passive and active conditioning strategies (Figure 4)., resulting in a completely open or closed house depending on the weather conditions at the time and adapted to the location where the competition was held.

The theoretical residential building to which the housing cell or prototype would belong is longitudinal: The sides with a greater surface area face north-south, where the sun's position is more vertical. This makes it easier to be protected from the sun. However, it did use solar shading strategies, such as a gallery to the north and a ventilated layer system to the south (constructed using a local bamboo variety called guadua).

Thermal inertia was minimized and natural ventilation was enhanced, always resulting in a side with sunlight and another in shadow, thus generating air flow. The house also had a solar chimney, which is a duct that complements the effect of natural cross ventilation by extracting hot air using the Venturi effect. 


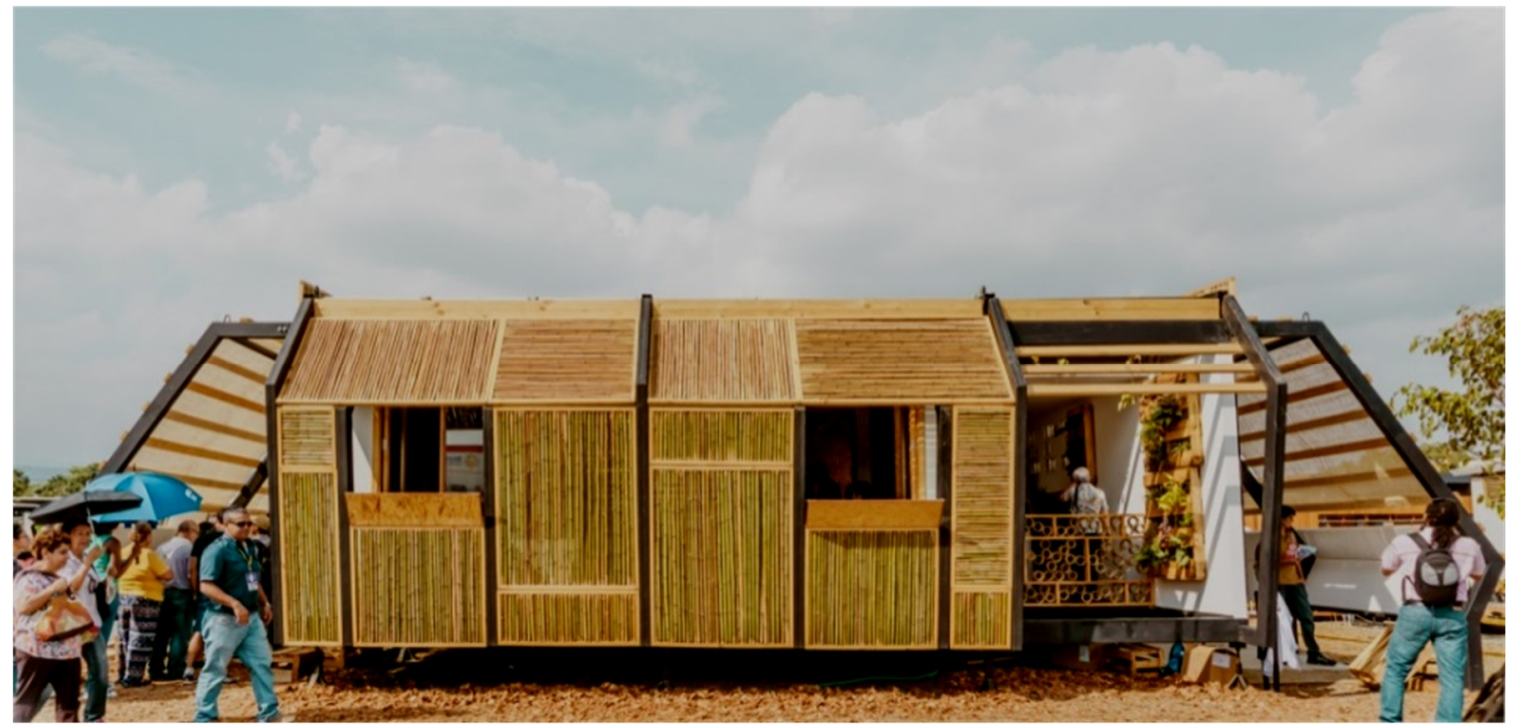

Figure 4. South side of the AURA Prototype.

- Fourth Prize: unSOLAR/U. Nacional de Medellín (Colombia)

After presenting the three award-winning models, which were very different typologies in terms of the use of passive or active conditioning strategies, the unSOLAR prototype (Figure 5) once again puts forward a completely open design using exclusively passive conditioning strategies, like the casa ALERO.

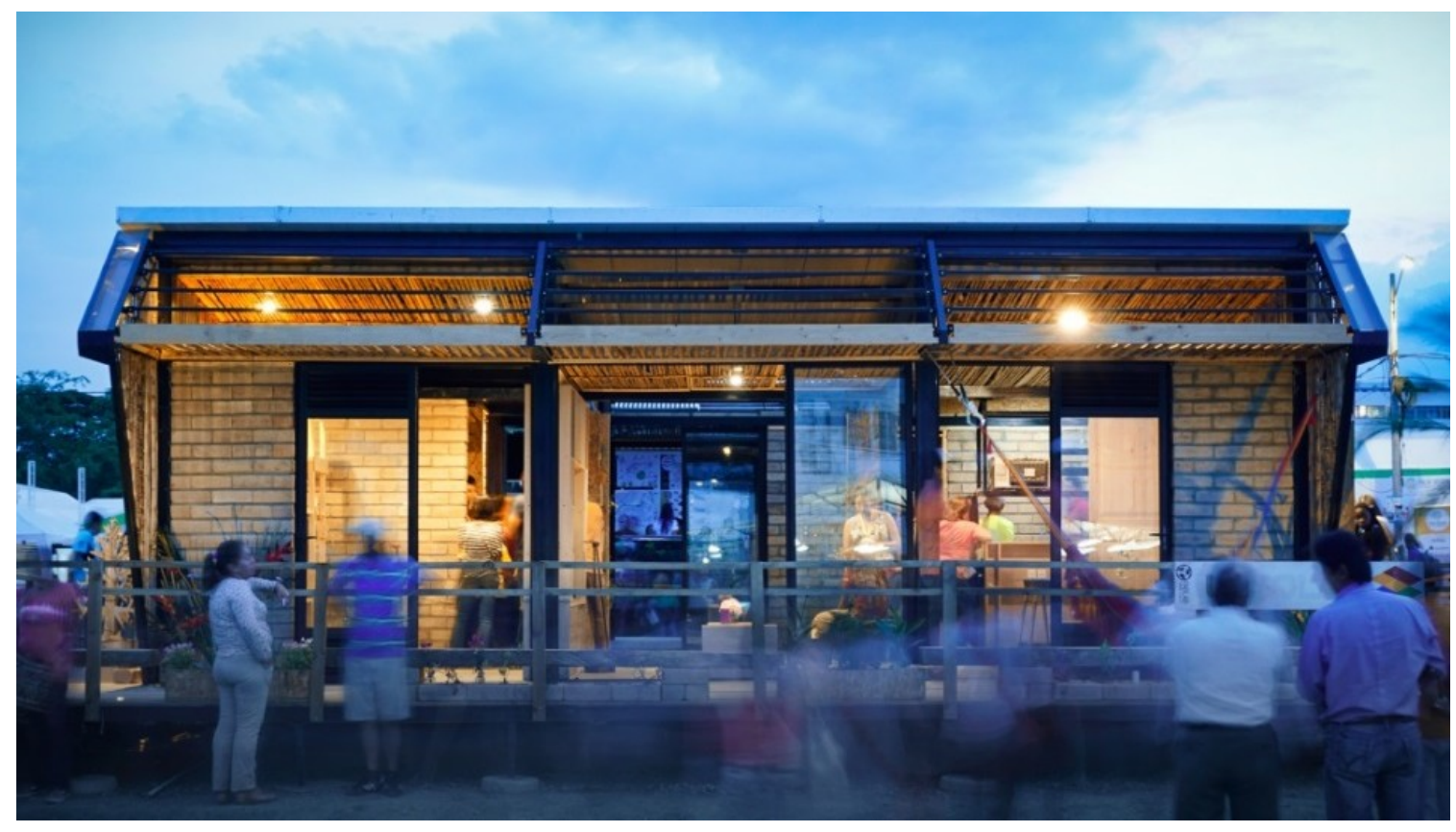

Figure 5. South side of unSOLAR.

Regarding its geometry, a notable aspect was its central courtyard that provides cross ventilation to all of the dwelling's rooms, which are protected from solar radiation by the same bamboo elements as those outlined in the previous project. Additionally, it is worth pointing out its traditional construction system, moving away from the prefabrication present in the three previous proposals. 
From the information gathered from each of the projects, Table 5 was generated, highlighting the use of the different strategies/technologies identified in the first level of analysis.

Table 5. Analysis and results of the prototypes.

\begin{tabular}{|c|c|c|c|c|c|}
\hline \multirow{2}{*}{\multicolumn{2}{|c|}{ TECHNOLOGIES // STRATEGIES }} & \multicolumn{4}{|c|}{ SD_LATIN AMERICA 2015} \\
\hline & & $\begin{array}{c}\text { ALERO } \\
\text { Colombia }\end{array}$ & $\begin{array}{l}\text { unSOLAR } \\
\text { Colombia }\end{array}$ & $\begin{array}{c}\text { AURA } \\
\text { Esp + Col }\end{array}$ & $\begin{array}{c}\text { URUG. } \\
\text { Uruguay }\end{array}$ \\
\hline \multicolumn{6}{|c|}{ ENERGY SAVING DESIGN AND PASSIVE TECHNOLOGIES } \\
\hline \multirow{6}{*}{ ENCLOSURE: } & Solar protection & $\bullet$ & $\bullet$ & $\bullet$ & $\bullet$ \\
\hline & Ventilated facade & & & $\bullet$ & $\bullet$ \\
\hline & Thermal insulation & & & $\bullet$ & $\bullet$ \\
\hline & Low emissivity gaps & & & $\bullet$ & $\bullet$ \\
\hline & Cross ventilation & $\bullet$ & $\bullet$ & • & • \\
\hline & Green cover & $\bullet$ & & & \\
\hline $\begin{array}{l}\text { THERMAL ENERGY } \\
\text { STORAGE }\end{array}$ & $\begin{array}{l}\text { Phase change materials } \\
\text { (PCM) }\end{array}$ & & & & $\bullet$ \\
\hline \multicolumn{6}{|c|}{ EFFICIENT ENERGY SERVICE SYSTEMS } \\
\hline \multirow{2}{*}{ SOLAR ENERGY } & Photovoltaic panels & $\bullet$ & $\bullet$ & $\bullet$ & $\bullet$ \\
\hline & Architectonic Integration & & $\bullet$ & $\bullet$ & \\
\hline $\begin{array}{l}\text { HVAC (Heating, } \\
\text { Ventilating and Air } \\
\text { Conditioning) }\end{array}$ & Heat recovery & & & $\bullet$ & $\bullet$ \\
\hline DWH & Solar water heating $(\mathrm{SWH})$ & $\bullet$ & $\bullet$ & $\bullet$ & $\bullet$ \\
\hline \multirow{2}{*}{ ILLUMINATION } & Light-emitting diodes LED & No data & No data & $\bullet$ & $\bullet$ \\
\hline & Daylight harvesting & $\bullet$ & $\bullet$ & $\bullet$ & $\bullet$ \\
\hline \multirow{2}{*}{$\begin{array}{l}\text { HOUSING } \\
\text { EQUIPMENT }\end{array}$} & Efficient appliances & $\bullet$ & $\bullet$ & $\bullet$ & $\bullet$ \\
\hline & Domotics/Monitoring & & & & $\bullet$ \\
\hline \multirow{2}{*}{ WATER CYCLE } & Greywater recycling & No data & No data & $\bullet$ & No data \\
\hline & Rainwater harvesting & $\bullet$ & No data & & No data \\
\hline
\end{tabular}

$\bullet$ is used to indicate the use of this technology.

After analyzing Table 5 and comparing its content to the third section of this article (literature review), the following was surmised:

There are two clearly contrasting models. On the one hand, casa ALERO and unSOLAR correspond to a type of housing that is completely open, entrusting the comfort of the house to passive conditioning strategies. Alternatively, Casa Uruguaya opted for a closed prototype, isolated from the exterior environment, in which the different variables can be managed regarding the exterior, thus being much more focused on active conditioning.

An intermediate position is presented by the AURA project, which proposed a covered but open space (zaguán, in popular Andalusian culture, or antejardín, in popular Colombian culture), corresponding to an adaptation to Latin-Mediterranean vernacular architecture, passively working on the climatic comfort of the different areas of the house. This balance, championed by the prototype presented by the University of Seville, worked remarkably well and, as a result, was recognized with the first prize in the comfort conditions contest (one of the 10 sections of the competition on which each of the participating prototypes was evaluated). 


\section{Graphic Results from Monitoring the Different Strategies}

In accordance with the above analysis, after establishing the context in which this first edition of the Solar Decathlon collegiate competition was held in Latin America, and comparing the strategies proposed by the four teams with the highest scores in the competition, it is worthwhile to graphically display the results of the continuous measurements carried out by the competition organizers, in order to thereby award the scores for the aforementioned comfort conditions contest of the SDLAC15. These measurements were carried out under equal conditions for all teams, at the same time and therefore with identical weather conditions.

The graphs show the entire competition period during which all the prototypes were monitored, from 5 to 14 December 2015. There was no rainfall during this time. It is worth noting that the city of Santiago de Cali is located at a latitude of 3.42 and an altitude of $926 \mathrm{~m}$. The climate conditions of this location are constant throughout the year, with no conventional seasons as in other latitudes, with the greatest thermal variations occurring between the day and the night.

The monitoring locations of the interior comfort parameters for each prototype were the living room and bedroom. However, the architecture presented by each prototype had no conventional boundaries between rooms and, therefore, the distribution of the houses could vary depending on needs throughout the day. As a sample, a plan of Casa AURA is included (Figure 6), showing the distribution of measurement locations, in this case.

Consequently, the first of the two graphs show the temperatures recorded for the four analyzed teams (Figure 7), verifying how casa AURA achieved a more stable temperature inside the house throughout the day, and obtaining higher temperatures than the completely open prototypes (casa ALERO and unSOLAR) when recording the minimum daytime temperatures, with descending levels in terms of the highest daily peaks.

Similarly, observing the graph of the relative humidity results (Figure 8), we can see how when the outdoor humidity is higher, the open prototypes perform more poorly than the closed prototypes or those equipped with active conditioning systems (casa Uruguaya and AURA). Therefore, as with the temperature graph, we can also see how the results obtained by casa AURA in terms of relative humidity are more stable than for the other competing prototypes.

However, although the graphs show the trends for each prototype in relation to temperature and humidity, showing which prototypes performed in a more stable manner, it is worthwhile to also know the percentage of time during which each of them was within the comfort range set by the competition: Temperature between 24 and $28{ }^{\circ} \mathrm{C}$ and humidity lower than $60 \%$.

Table 6 shows how the Casa Uruguaya prototype maintained its indoor space in the thermal comfort range for the greatest percentage of time. However, Casa AURA was the prototype that most successfully controlled humidity. As we are dealing with measurements recorded in a tropical climate, the latter is undoubtedly the most significant. In relation to the sum of temperature + humidity (hygrothermal conditions), both the Casa Uruguaya and Casa AURA obtained very similar percentages.

Table 6. Percentage of time in the comfort range.

\begin{tabular}{ccccc}
\hline Teams & La Casa Uruguaya & CASA ALERO & CASA AURA & unSOLAR \\
\hline Time in temp. comfort range (\%) & $79.9 \%$ & $24.3 \%$ & $65.90 \%$ & $36 \%$ \\
\hline Time in humidity comfort range (\%) & $33.60 \%$ & $42.5 \%$ & $46 \%$ & $40.60 \%$ \\
\hline $\begin{array}{c}\text { Time in temp. + humidity comfort } \\
\text { range (\%) }\end{array}$ & $21.15 \%$ & $3.3 \%$ & $19.5 \%$ & $8.4 \%$ \\
\hline
\end{tabular}




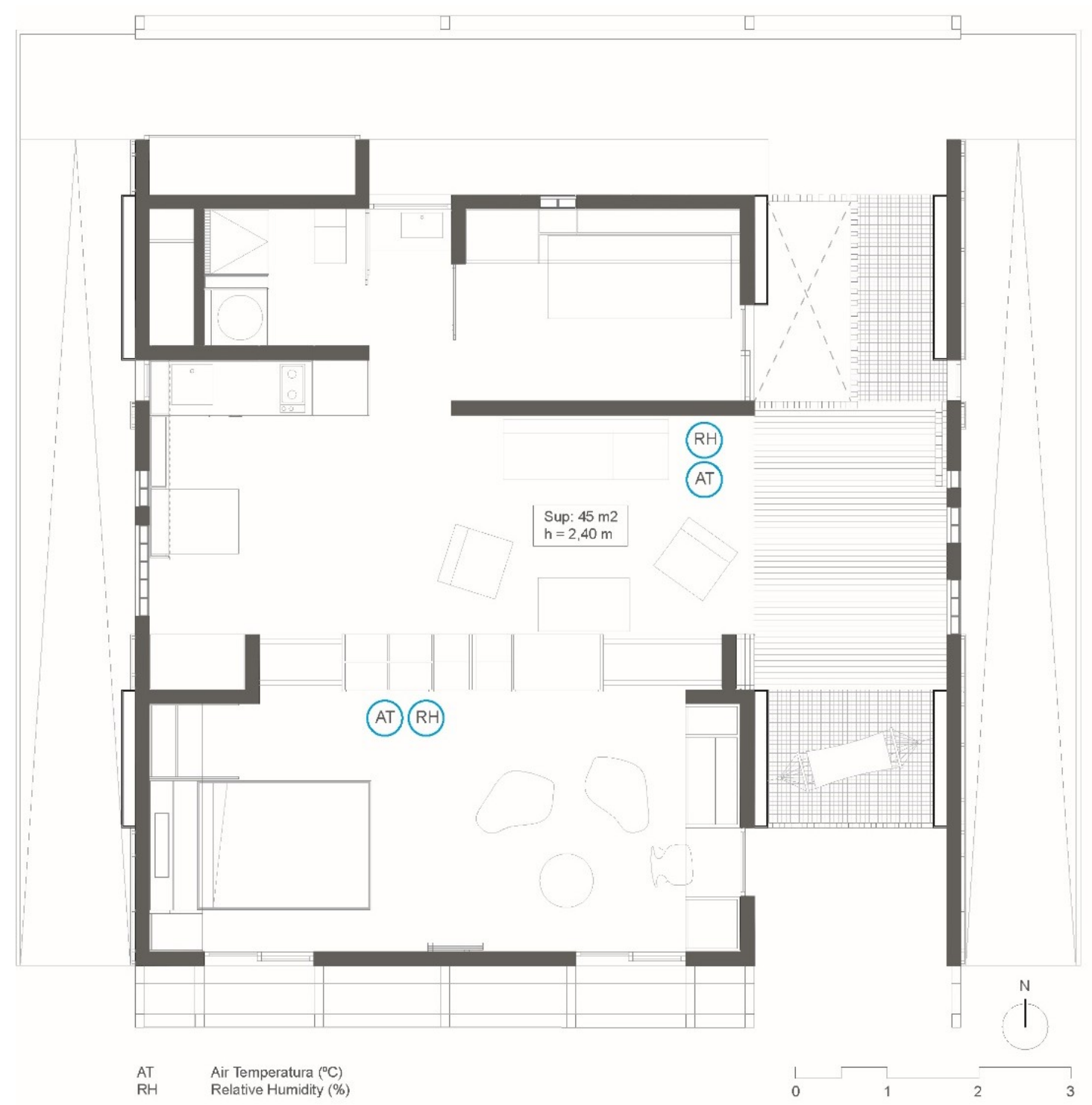

Figure 6. Plan of the AURA Prototype, with temperature and humidity sensors.

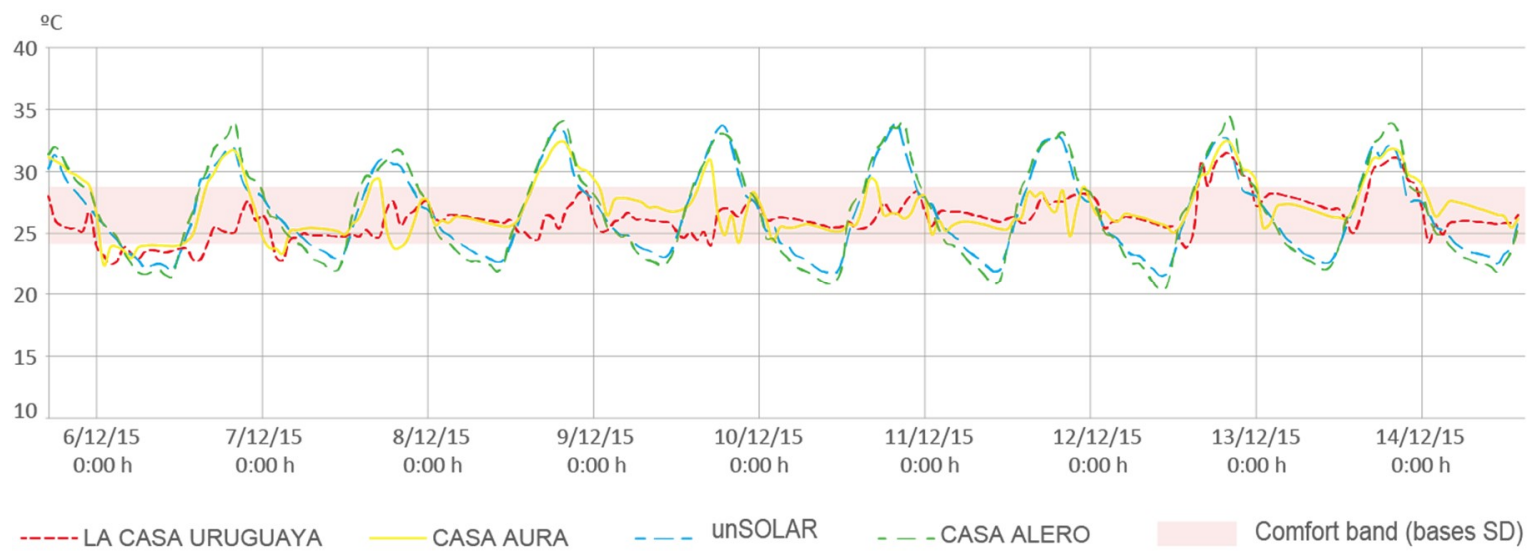

Figure 7. Comparative temperature graph; day 10 of the competition. 


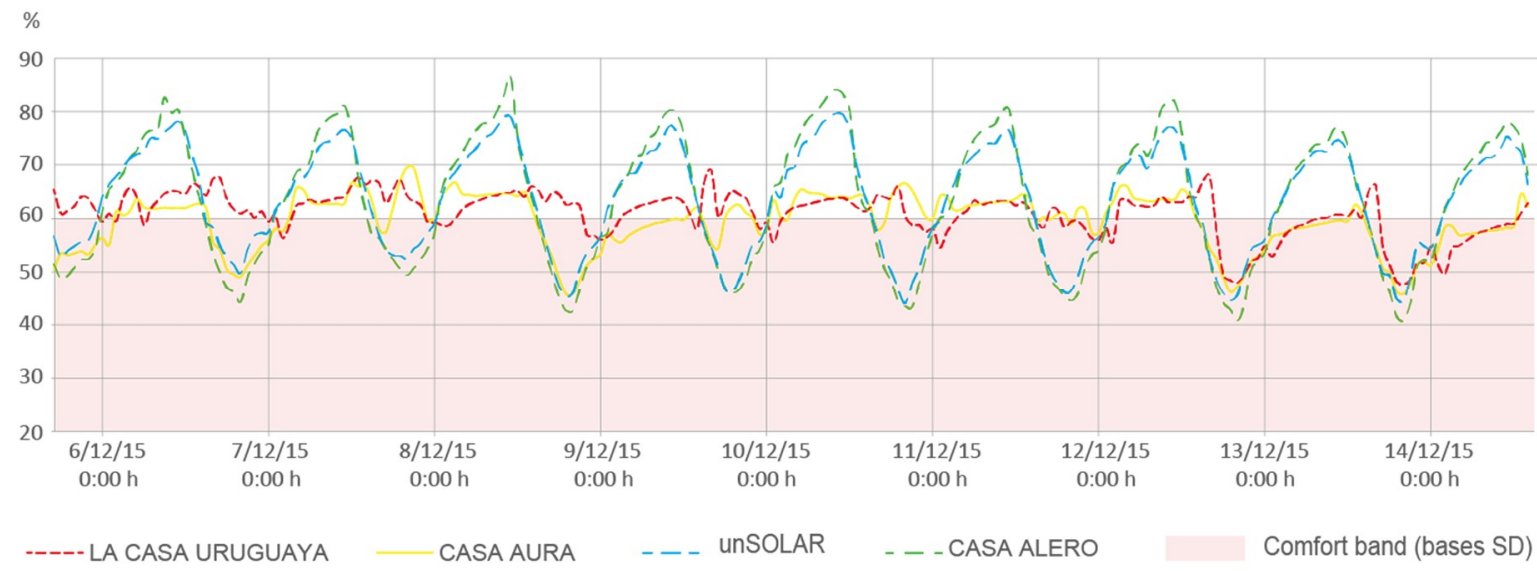

Figure 8. Comparative humidity graph; day 10 of the competition.

It is worth noting that in the comfort conditions contest, in addition to the thermal and humidity conditions, they were also assessed on light and noise conditions. In the overall calculation of this contest, the Casa AURA scored the most points regarding the other participating teams, and therefore was awarded first prize.

\section{Discussion and Conclusions}

From the analysis performed (and by studying the applicable regulations), it is clear that there must be specific regulations that oblige all agents and all training and research centers to work towards the production of more sustainable buildings. However, after thoroughly delving into the competition rules, it can be concluded that these are not sensitive to the local component of the location where the final phase of the competition is proposed and carried out. This makes it possible that society would find it difficult to accept solutions that obtained very high scores in most of the 10 contests that comprise the competition, and, therefore, it would not be possible for the desired conceptual and technological transfer to materialize. It is essential that the location is able to industrially handle these technologies so that the prototypes may become a real model for transfer.

Alternatively, and focusing in particular on aspects related to the prototypes' environmental design, it seems that the relationship between passive and active elements has not always been properly balanced. Accordingly, of the four models analyzed, only one (the Aura project) used a strategy that combines a functional typology that was adapted to its context with an adequate balance between passive strategies and active equipment, which provided an adequate performance.

Although the hygrothermal data from the Casa Uruguaya and the Casa AURA were found to be very similar when analyzed regarding the comfort range, an architectural design that depends exclusively on active conditioning actions is considered socio-culturally decontextualised for an environment such as that of Santiago de Cali, in particular when the competition rules impinged on working in a social housing context, for the first time in the history of the competition.

Finally, although the fundamental aspects for transferring results from the Solar Decathlon Competition to the analyzed context are clearly established, it is necessary to continue working to adjust the rules of this collegiate competition for sustainable habitats by producing appropriate national regulations and properly training the agents of the building process if the intention is to truly achieve a high potential for transfer in the short term.

In order to do so, continuing this line of action as a methodological opportunity (for learning through the completion of higher education projects), in search of innovation and transfer, will be a priority.

Author Contributions: All authors conceived and designed the experiments; all authors performed the experiments; all authors analyzed the data; all authors have written, reviewed, and approved the final manuscript. 
Funding: This research received no external funding.

Acknowledgments: Images of the prototypes were provided by Gustavo Correa (Universidad del Valle, Santiago de Cali, Colombia).

Conflicts of Interest: The authors declare no conflict of interest.

\section{References}

1. Gundes, S. The Use of Life Cycle Techniques in the Assessment of Sustainability. Procedia Soc. Behav. Sci. 2016, 216, 916-922. [CrossRef]

2. Li, Z. A new life cycle impact assessment approach for buildings. Build. Environ. 2006, 41, 1414-1422. [CrossRef]

3. Gómez de Cózar, J.C.; Garcia Martinez, A.; ArizaLópez, I.; Ruiz Alfonsea, M. Lightweight and Quickly Assembled: The Most Eco-Efficient Model for Architecture. Int. J. Comput. Methods Exp. Meas. 2017, 5, 539-550. [CrossRef]

4. Herrera-Limones, R. La Urdimbre Sostenible Como Táctica Para un Hacer Arquitectónico: De la Arquitectura de Países Cálidos Hasta Los Nuevos Escenarios Y Modos de Vida Emergentes, a Través de la Dimensión Dialógica. Ph.D. Thesis, Universidad de Sevilla, Sevilla, Spain, 2013.

5. Solar Decathlon Latin America \& Caribbean 2015. RULES Final Version. Available online: www. solardecathlon2015.com.co (accessed on 15 December 2015).

6. Cao, X.; Dai, X.; Liu, J. Building energy-consumption status worldwide and the state-of-the-art technologies for zero-energy buildings during the past decade. Energy Build. 2016, 128, 198-213. [CrossRef]

7. Liu, Z.; Liu, Y.; He, B.J.; Xu, W.; Jin, G.; Zhang, X. Application and suitability analysis of the key technologies in nearly zero energy buildings in China. Renew. Sustain. Energy Rev. 2019, 101, 329-345. [CrossRef]

8. D'Agostino, D.; Mazzarella, L. What is a Nearly zero energy building? Overview, implementation and comparison of definitions. J. Build. Eng. 2018, 21, 200-212. [CrossRef]

9. Terrados, F.J.; Moreno, D. "Patio" and "Botijo": Energetic strategies' architectural integration in "Patio 2.12" prototype. Energy Build. 2014, 83, 70-88. [CrossRef]

10. Serra Soriano, B.; VerdejoGimeno, P.; Díaz Segura, A.; Merí De La Maza, R. Assembling sustainable ideas: The construction process of the proposal SMLsystem at the Solar Decathlon Europe 2012. Energy Build. 2014, 83, 185-194. [CrossRef]

11. Irulegi, O.; Torres, L.; Serra, A.; Mendizabal, I.; Hernández, R. The Ekihouse: An energy self-sufficient house based on passive design strategies. Energy Build. 2014, 83, 57-69. [CrossRef]

12. Kazanci, O.B.; Skrupskelis, M.; Sevela, P.; Pavlov, G.K.; Olesen, B.W. Sustainable heating, cooling and ventilation of a plus-energy house via photovoltaic/thermal panels. Energy Build. 2014, 83, 122-129. [CrossRef]

13. Barbosa, S.; Ip, K. Perspectives of double skin façades for naturally ventilated buildings: A review. Renew. Sustain. Energy Rev. 2014, 40, 1019-1029. [CrossRef]

14. Nizovtsev, M.I.; Belyi, V.T.; Sterlygov, A.N. The facade system with ventilated channels for thermal insulation of newly constructed and renovated buildings. Energy Build. 2014, 75, 60-69. [CrossRef]

15. Al-Homoud, D.M.S. Performance characteristics and practical applications of common building thermal insulation materials. Build. Environ. 2005, 4040, 353-366. [CrossRef]

16. Hee, W.J.; Alghoul, M.A.; Bakhtyar, B.; Elayeb, O.; Shameri, M.A.; Alrubaih, M.S.; Sopian, K. The role of window glazing on daylighting and energy saving in buildings. Renew. Sustain. Energy Rev. 2015, 42, 323-343. [CrossRef]

17. Tonelli, C.; Converso, S. Digital mirror: A method to shape smart citizenship. Energy Build. 2014, 83, $173-180$. [CrossRef]

18. Chan, H.-Y.; Riffat, S.B.; Zhu, J. Review of passive solar heating and cooling technologies. Renew. Sustain. Energy Rev. 2010, 1414, 781-789. [CrossRef]

19. Juanicó, L. A new design of roof-integrated water solar collector for domestic heating and cooling. Sol. Energy 2008, 8282, 481-492. [CrossRef]

20. Richman, R.C.; Pressnail, K.D. A more sustainable curtain wall system: Analytical modeling of the solar dynamic buffer zone (SDBZ) curtain wall. Build. Environ. 2009, 44, 1-10. [CrossRef] 
21. Campaniço, H.; Hollmuller, P.; Soares, P.M.M. Assessing energy savings in cooling demand of buildings using passive cooling systems based on ventilation. Appl. Energy 2014, 134, 426-438. [CrossRef]

22. Schulze, T.; Eicker, U. Controlled natural ventilation for energy efficient buildings. Energy Build. 2013, 56, 221-232. [CrossRef]

23. Benhammou, M.; Draoui, B. Parametric study on thermal performance of earth-to-air heat exchanger used for cooling of buildings. Renew. Sustain. Energy Rev. 2015, 44, 348-355. [CrossRef]

24. Vijayaraghavan, K. Green roofs: A critical review on the role of components, benefits, limitations and trends. Renew. Sustain. Energy Rev. 2016, 57, 740-752. [CrossRef]

25. Chen, J.; Xue, X.; Qu, M.; Han, X.; Kang, Y. Experimental analysis on dehumidification performance of an indoor passive falling film liquid desiccant moisture receptacle. Energy Build. 2016, 125, 161-170. [CrossRef]

26. Tyagi, V.V.; Buddhi, D. PCM thermal storage in buildings: A state of art. Renew. Sustain. Energy Rev. 2007, 11, 1146-1166. [CrossRef]

27. Rodriguez-Ubinas, E.; Ruiz-Valero, L.; Vega, S.; Neila, J. Applications of Phase Change Material in highly energy-efficient houses. Energy Build. 2012, 50, 49-62. [CrossRef]

28. Kenisarin, M.; Mahkamov, K. Passive thermal control in residential buildings using phase change materials. Renew. Sustain. Energy Rev. 2016, 55, 371-398. [CrossRef]

29. Pandey, A.K.; Tyagi, V.V.; Selvaraj, J.A.; Rahim, N.A.; Tyagi, S.K. Recent advances in solar photovoltaic systems for emerging trends and advanced applications. Renew. Sustain. Energy Rev. 2016, 53, 859-884. [CrossRef]

30. Terrados-Cepeda, F.J.; Baco-Castro, L.; Moreno-Rangel, D. Patio 2.12: Vivienda prefabricada, sostenible, autosuficiente y energéticamente eficiente. Participación en la competición Solar DecathlonEurope 2012. Inf. Construcción 2015, 67, e088. [CrossRef]

31. Aldegheri, F.; Baricordi, S.; Bernardoni, P.; Brocato, M.; Calabrese, G.; Guidi, V.; Vincenzi, D. Building integrated low concentration solar system for a self-sustainable Mediterranean villa: The Astonyshine house. Energy Build. 2014, 77, 355-363. [CrossRef]

32. Pantic, S.; Candanedo, L.; Athienitis, A.K. Modeling of energy performance of a house with three configurations of building-integrated photovoltaic/thermal systems. Energy Build. 2010, 42, 1779-1789. [CrossRef]

33. Good, C.; Andresen, I.; Hestnes, A.G. Solar energy for net zero energy buildings-A comparison between solar thermal, PV and photovoltaic-thermal (PV/T) systems. Sol. Energy 2015, 122, 986-996. [CrossRef]

34. Ayhan, D.; Sağlam, S. A technical review of building-mounted wind power systems and a sample simulation model. Renew. Sustain. Energy Rev. 2012, 16, 1040-1049. [CrossRef]

35. Emmi, G.; Zarrella, A.; De Carli, M.; Galgaro, A. An analysis of solar assisted ground source heat pumps in cold climates. Energy Convers. Manag. 2015, 106, 660-675. [CrossRef]

36. Stolarski, M.J.; Krzyżaniak, M.; Warmiński, K.; Śnieg, M. Energy, economic and environmental assessment of heating a family house with biomass. Energy Build. 2013, 66, 395-404. [CrossRef]

37. Fabrizio, E.; Seguro, F.; Filippi, M. Integrated HVAC and DHW production systems for Zero Energy Buildings. Renew. Sustain. Energy Rev. 2014, 40, 515-541. [CrossRef]

38. Luque, R.; Herrero-Davila, L.; Campelo, J.M.; Clark, J.H.; Hidalgo, J.M.; Luna, D.; Romero, A.A. Biofuels: A technological perspective. Energy Environ. Sci. 2008, 11, 513-596. [CrossRef]

39. OuldAmrouche, S.; Rekioua, D.; Rekioua, T.; Bacha, S. Overview of energy storage in renewable energy systems. Int. J. Hydrogen Energy 2016, 41, 20914-20927. [CrossRef]

40. Chatzivasileiadi, A.; Ampatzi, E.; Knight, I. Characteristics of electrical energy storage technologies and their applications in buildings. Renew. Sustain. Energy Rev. 2013, 25, 814-830. [CrossRef]

41. Cuce, P.M.; Riffat, S. A state-of-the-art review of evaporative cooling systems for building applications. Renew. Sustain. Energy Rev. 2016, 54, 1240-1249. [CrossRef]

42. Al-Abidi, A.A.; Bin Mat, S.; Sopian, K.; Sulaiman, M.Y.; Lim, C.H.; Th, A. Review of thermal energy storage for air conditioning systems. Renew. Sustain. Energy Rev. 2012, 16, 5802-5819. [CrossRef]

43. Cuce, P.M.; Riffat, S. A comprehensive review of heat recovery systems for building applications. Renew. Sustain. Energy Rev. 2015, 47, 665-682. [CrossRef]

44. Mardiana-Idayu, A.; Riffat, S.B. Review on heat recovery technologies for building applications. Renew. Sustain. Energy Rev. 2012, 16, 1241-1255. [CrossRef] 
45. Rhee, K.-N.; Kim, K.W. A 50-year review of basic and applied research in radiant heating and cooling systems for the built environment. Build. Environ. 2015, 91, 166-190. [CrossRef]

46. Okochi, G.S.; Yao, Y. A review of recent developments and technological advancements of variable-air-volume (VAV) air-conditioning systems. Renew. Sustain. Energy Rev. 2016, 59, 784-817. [CrossRef]

47. Zhu, Y.; Jin, X.; Fang, X.; Du, Z. Optimal control of combined air conditioning system with variable refrigerant flow and variable air volume for energy saving. Int. J. Refrig. 2014, 42, 14-25. [CrossRef]

48. Gautam, A.; Chamoli, S.; Kumar, A.; Singh, S. A review on technical improvements, economic feasibility and world scenario of solar water heating system. Renew. Sustain. Energy Rev. 2017, 68, 541-562. [CrossRef]

49. Buker, M.S.; Riffat, S.B. Solar assisted heat pump systems for low temperature water heating applications: A systematic review. Renew. Sustain. Energy Rev. 2016, 55, 399-413. [CrossRef]

50. Maraver, D.; Sin, A.; Royo, J.; Sebastián, F. Assessment of CCHP systems based on biomass combustion for small-scale applications through a review of the technology and analysis of energy efficiency parameters. Appl. Energy 2013, 102, 1303-1313. [CrossRef]

51. Frascarolo, M.; Martorelli, S.; Vitale, V. An innovative lighting system for residential application that optimizes visual comfort and conserves energy for different user needs. Energy Build. 2014, 83, 217-224. [CrossRef]

52. Yu, X.; Su, Y. Daylight availability assessment and its potential energy saving estimation-A literature review. Renew. Sustain. Energy Rev. 2015, 52, 494-503. [CrossRef]

53. Cabeza, L.F.; Urge-Vorsatz, D.; McNeil, M.A.; Barreneche, C.; Serrano, S. Investigating greenhouse challenge from growing trends of electricity consumption through home appliances in buildings. Renew. Sustain. Energy Rev. 2014, 36, 188-193. [CrossRef]

54. Zamora-Martínez, F.; Romeu, P.; Botella-Rocamora, P.; Pardo, J. On-line learning of indoor temperature forecasting models towards energy efficiency. Energy Build. 2014, 83, 162-172. [CrossRef]

55. Carolina, D.; Motta, O.; Aguilar, J.S.; Hurtado Aguirre, E. Una revisión a la reglamentación e incentivos de las energías renovables en colombia a reviewtoregulation and incentives of renewableenergies in Colombia. Rev. Fac. Cienc. Econ. 2012, 20, 55-67.

56. Mejía, G. A Comparative Study between the Energetic Efficiency Legislation in Colombia and Spain. Rev. EAN 2014, 77, 122-135. [CrossRef]

57. Rodríguez Patarroyo, M. Fomento de las energías renovables en Colombia: Entre contradicciones e iniciativas fallidas. Rev. Vasca Adm. Pública 2014, 99, 2581-2604. 